\begin{tabular}{|l|c|c|c|c|}
\hline $\begin{array}{l}\text { Cuadernos de Investigación Geográfica } \\
\text { Geographical Research Letters }\end{array}$ & 2019 & N $^{\circ} 45(2)$ & pp. 687-708 & eISSN 1697-9540 \\
\hline
\end{tabular}

\title{
THE USE OF MULTIVARIATE STATISTICAL ANALYSIS AND SOIL QUALITY INDICES AS TOOLS TO BE INCLUDED IN REGIONAL MANAGEMENT PLANS. A CASE STUDY FROM THE MASHHAD PLAIN, IRAN
}

\author{
J. RODRIGO-COMINO ${ }^{1}$, A. KESHAVARZI ${ }^{2 *}$, \\ A. BAGHERZADEH ${ }^{3}$, E.C. BREVIK ${ }^{4}$ \\ ${ }^{1}$ Instituto de Geomorfología y Suelos, Department of Geography, University of Málaga, 29071-Málaga, Spain. \\ ${ }^{2}$ Laboratory of Remote Sensing and GIS, Department of Soil Science, University of Tehran, \\ P.O. Box 4111, Karaj 31587-77871, Iran. \\ ${ }^{3}$ Department of Agriculture, Islamic Azad University, Mashhad Branch, \\ Emamyeh Boilevard, P.O. Box 91735-413, Mashhad, Iran. \\ ${ }^{4}$ Department of Natural Sciences, 291 Campus Drive, Dickinson State University, \\ Dickinson, ND, 58061, USA.
}

\begin{abstract}
Several methods have been used to model reality and explain soil pedogenesis and evolution. However, there is a lack of information about which soil properties truly condition soil quality indicators and indices particularly at the pedon scale and at different soil depths to be used in land management planning. Thus, the main goals of this research were: $i$ ) to assess differences in soil properties (particle size, saturation point, bulk density, soil organic carbon, $\mathrm{pH}$ and electrical conductivity) at different soil depths (0-30 and 30-60 cm); ii) to check their statistical correlation with soil quality indicators (CEC, total N, Olsen-P, available K, exchangeable Na, calcium carbonate equivalent, $\mathrm{Fe}, \mathrm{Mn}, \mathrm{Zn}$, and $\mathrm{Cu}$ ); and, iii) to elaborate a soil quality index and maps for each soil layer. To achieve this, forty-eight soil samples were analysed in the laboratory and subjected to statistical analyses by ANOVA, Spearman Rank coefficients and Principal Component Analyses. Finally, a soil quality index was developed based on indicators of sensitivity. The study was conducted in a semiarid catchment in northeast Iran with irrigated farming and well-documented land degradation issues. We found that: $i$ ) organic carbon and bulk density were not similar in the topsoil and subsoil; ii) calcium carbonate and sand content conditioned organic carbon content and bulk density; iii) organic carbon showed the highest correlations with soil quality indicators; iv) particle size conditioned cation-exchange capacity; and, v) heavy metals such as $\mathrm{Mn}$ and $\mathrm{Cu}$ were highly correlated with organic carbon due to non-suitable agricultural practices. Based on the communality analysis to map of soil quality, $C E C, \mathrm{Mn}, \mathrm{Zn}$, and $\mathrm{Cu}$ had the highest weights $(\geq 0.11)$ at both depths, coinciding with the same level of relevance in the multivariate analysis. Exchangeable $\mathrm{Na}, \mathrm{CaCO}_{3}$ and $\mathrm{Fe}$ had the lowest weights $(\leq 0.1)$ and $\mathrm{N}, \mathrm{P}$, and $\mathrm{K}$ had intermediate weights (0.1-0.11). In general, the map of the soil quality index shows a lower soil quality in the subsoil increment than in the topsoil.
\end{abstract}


El uso de análisis estadístico multivariante y de índices de calidad del suelo como herramientas que deben incluirse en los planes de gestión regional. El caso de la llanura de Mashhad, Irán

RESUMEN. Muchos métodos permiten modelizar la realidad para tratar de explicar la formación y evolución del suelo. Sin embargo, a una escala suelo y a diferentes profundidades, no existe una gran cantidad de estudios que también mencionen los indicadores de calidad para ser incluidos en la ordenación del territorio. Por lo tanto, los principales objetivos de esta investigación son: i) evaluar las diferencias entre propiedades del suelo (tamaño de partículas, punto de saturación, densidad aparente, carbono orgánico, $\mathrm{pH}$ y conductividad eléctrica) a diferentes profundidades $(0-30 \mathrm{~cm}$ y 30-60 cm); ii) su posible correlación estadística con indicadores de calidad de suelo (capacidad de intercambio catiónico, $N$ total, Olsen- $P$, $K$ disponible, $N$ a intercambiable, carbonato cálcico equivalente, $\mathrm{Fe}, \mathrm{Mn}, \mathrm{Zn}$ y $\mathrm{Cu}) ; \mathrm{y}$, iii) elaborar un índice de calidad del suelo con su respectivo mapa para cada capa estudiada. Para alcanzar dicho objetivo, 48 muestras fueron recogidas y analizadas en el laboratorio, comparadas con diferentes métodos estadísticos (ANOVA, correlación de Spearman y análisis de componentes principales) y utilizadas para la creación de un índice de calidad del suelo en una cuenca de un ambiente semiárido al Noreste de Irán, caracterizada por una agricultura por irrigación y documentados procesos de degradación. Las principales conclusiones alcanzadas fueron: i) el carbono orgánico y la densidad aparente fueron diferentes para cada profundidad; ii) el carbonato cálcico y el contenido en arenas estaba altamente correlacionado con el carbono orgánico y la densidad aparente; iii) el contenido en carbono orgánico mostró la mejor correlación con los indicadores de calidad del suelo; iv) el tamaño de las partículas del suelo condicionó la capacidad de intercambio catiónico; $y, v)$ los metales pesados como el Mn y el Cu estuvieron fuertemente correlacionados con el carbono orgánico debido, posiblemente, a las malas prácticas agrícolas. Basados en el análisis de comunalidad del índice de calidad del suelo, para ambas profundidades, la capacidad de intercambio catiónico, $\mathrm{Mn}, \mathrm{Zn}$ y $\mathrm{Cu}$ obtuvieron los mayores pesos, coincidiendo con su importancia dentro del análisis multivariante realizado anteriormente. Por el contrario, el $\mathrm{Na}$ intercambiable, $\mathrm{CaCo}_{3}$ y el Fe obtuvieron los valores más bajos. N, P y K alcanzaron valores intermedios. En general, el mapa de calidad del suelo mostró valores menores en el horizonte sub-superficial que en la capa superficial.

Key words: soil properties, soil quality indicators, irrigation farming, semiarid area, land degradation, land management planning, Mashhad Plain, Iran.

Palabras clave: propiedades del suelo, indicadores de calidad del suelo, agricultura irrigada, área semiárida, degradación del territorio, plan de gestión regional, llanura de Mashhad, Irán. 
*Corresponding author: Ali Keshavarzi, Laboratory of Remote Sensing and GIS, Department of Soil Science, University of Tehran, P.O. Box 4111, Karaj 31587-77871, Iran.E-mail address: alikeshavarzi@ut.ac.ir

\section{Introduction}

Land degradation affects soil quality in many semiarid areas and is one of the most important concerns of humankind (Armenise et al., 2013; Qi et al., 2009). Conservation strategies designed by policymakers and farmers should be structured to protect soil quality and fertility (Calleja-Cervantes et al., 2015). Specifically, soil erosion and contamination are two of the most important causes of soil quality degradation (GarcíaRuiz et al., 2015; Li et al., 2017).

In natural semiarid landscapes, high temperatures and evapotranspiration rates and extreme rains concentrated in a few events are the most important factors driving soil quality (Zeraatpishe and Khormali, 2012). The generation of soil crusts (Singer and Shainberg, 2004) or the loss of fine particles such as silt or clays (Bruand and Tessier, 2000; TorresSallan et al., 2017) are clear signals of decreasing soil quality. In anthropogenic areas such as cultivated valleys, researchers also have to pay attention to other variables such as the intensive use of organic amendments (Fernández-Calviño et al., 2017), irrigation systems (García-Garizábal et al., 2017) and land use changes such as grazing or abandonment (Gutzler et al., 2015; Khaledian et al., 2017a). The establishment of clear soil degradation signals such as soil compaction, increase in heavy metals, loss of soil fertility and topsoil depletion can allow us to quantify degradation (Mwango et al., 2015; Pulido et al., 2017).

Several recent studies have focused on detecting soil parameters that can be used as soil quality indicators in topsoil (Liu et al., 2017). Results have demonstrated that some well-known chemical and physical properties have significant correlations. For example, soil texture has a high correlation with cation-exchange capacity (CEC), aggregate stability and soil water content (Khaledian et al., 2017a; Mamedov et al., 2017); soil organic carbon (SOC) is also well-correlated with aggregate stability, soil nutrients and biodiversity (Acín-Carrera et al., 2013; Wang et al., 2016); and bulk density (BD) with electrical conductivity (EC), clay content and soil porosity (Nasri et al., 2015). Heavy metals such as $\mathrm{Fe}, \mathrm{Mn}, \mathrm{Zn}$ and $\mathrm{Cu}$ are widely used as soil quality indicators because of their effect on soil fertility and corresponding plant responses (Pezeshki and DeLaune, 2012; Sparrow and Uren, 2014; Tao et al., 2007).

However, research into soil properties and soil quality indicators is not common in semiarid landscapes in developing countries with a combination of traditional land uses such as grazing and irrigated farming. In Iran, research has focused on the development of models and pedotransfer functions to clarify these kinds of relationships (Hosseini et al., 2017; Keshavarzi et al., 2018; Shiri et al., 2017). In addition, there is a lack of studies focused on the variation in and interpretation of soil properties at different depths and how they could influence soil quality indicators. Thus, the first goal of this research was to evaluate differences in soil properties at different soil depths and their statistical correlations with soil quality indicators. Moreover, the research aimed to discover which 
group of factors can explain the variance and weight of soil properties and quality indicators at the pedon scale in a semi-arid catchment. Thus, we developed a soil quality index and soil quality maps. To achieve this goal, a semiarid catchment was selected in northeast Iran.

\section{Materials and methods}

\subsection{Study area}

The study area is in Khorasan-e-Razavi Province, northeast Iran, specifically in the Mashhad Plain between latitudes $35^{\circ} 59^{\prime} \mathrm{N}$ to $37^{\circ} 04^{\prime} \mathrm{N}$ and longitudes $58^{\circ} 22^{\prime} \mathrm{E}$ to $60^{\circ} 07^{\prime}$ E (Fig. 1). Soil samples were collected from sites with a mean elevation of $1200 \mathrm{~m}$ a.s.l. The highest altitudes in nearby areas are up to $2700 \mathrm{~m}$ a.s.l. The geological units are shown in Figure 2. Volcanic rocks such as andesites are located in the northwest. Along the west and north parts, limestones and dolomites are the most common rock units. Red marls, gypsiferous marls, sandstones and conglomerates are found in between. The second most extensive geological unit is the fluvial valley characterized by conglomerates and piedmont. Granites and metamorphic rocks such as schists, phyllites, slates and meta-sands can be found in the southern part of the study area. The surrounding landscapes are composed of pediment plains, upper terraces, gravelly colluvial fans, and plateaus. The climate is semi-arid, with rainfall averaging about $222.1 \mathrm{~mm} \mathrm{yr}^{-1}$ and temperatures about $15.8^{\circ} \mathrm{C}$ (Keshavarzi et al., 2016). The soils are classified as Calcaric Cambisols, Gypsic Regosols, Calcaric Regosols and Calcaric Fluvisols (WRB Working Group, 2014) with horizons that are high in calcium carbonate content and low in soil organic carbon. The main land uses in the study area are also shown in Figure 2. Irrigated farming and a mixture of different crops are located along the valley. Rangelands are the most common land use in the mountainous area. Dryland farming practices are carried out in the eastern part of the study area and at specific points along the water courses. Low to very low forest areas are scarce.

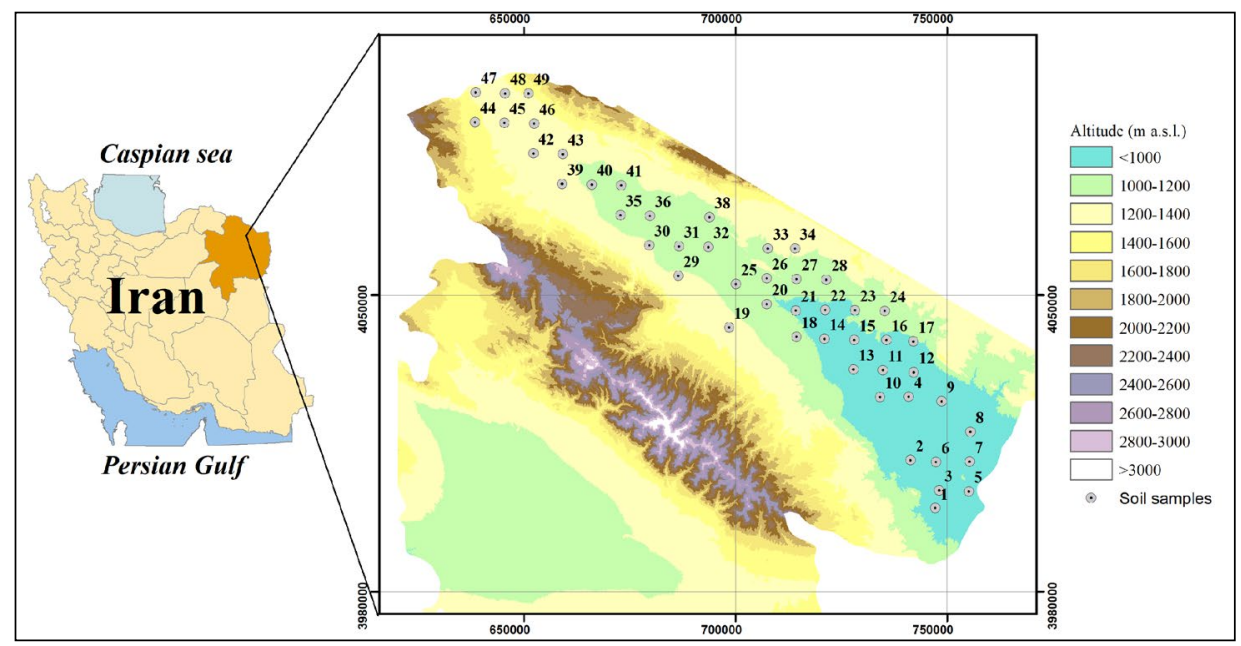

Figure 1. Location and general topography of the study area. 

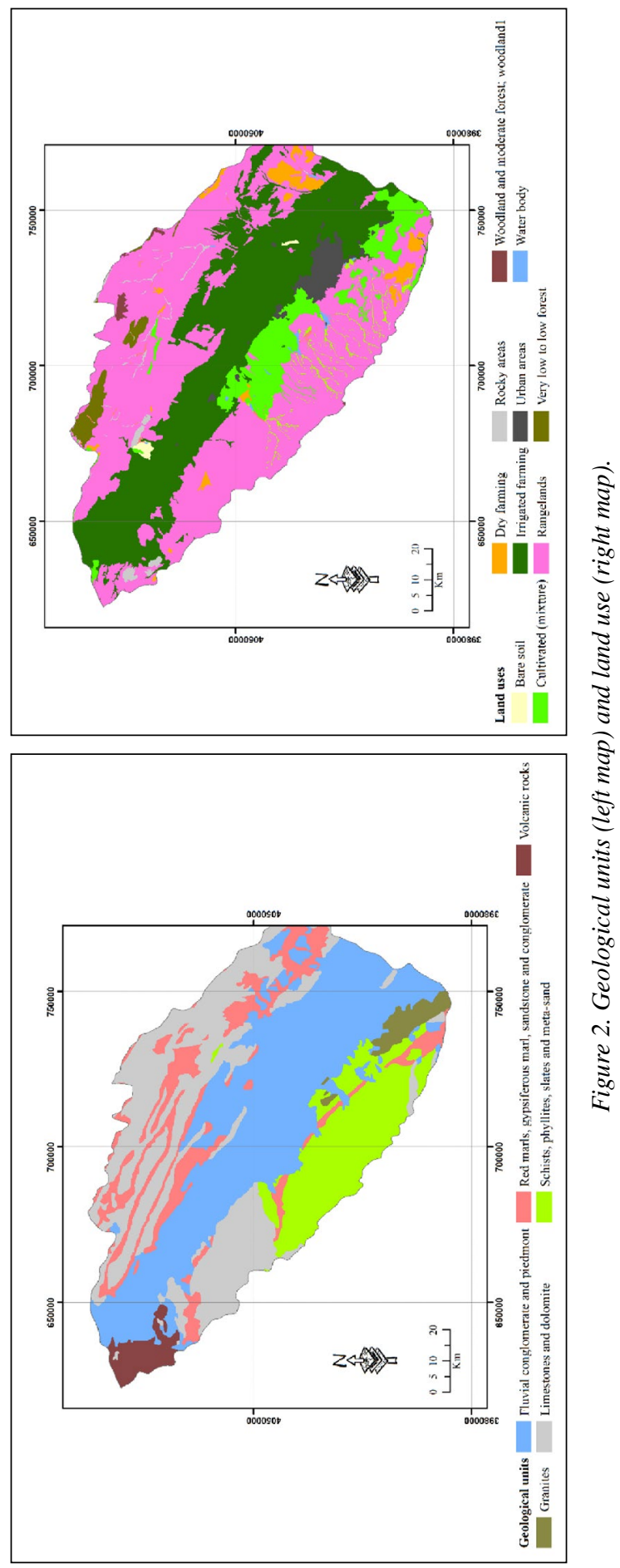


\subsection{Soil sampling and laboratory analysis}

Forty-eight representative soil profiles were selected using a stratified random sampling technique, similar to the procedures explained by Arnab (2017) and Christofides (2005). Soil samples were taken from two different depth intervals, $0-30 \mathrm{~cm}$ and $30-60 \mathrm{~cm}$. We decided to follow this separation instead of soil horizons because our goal was to focus on soil quality in the topsoil, or the part of the soil influenced by crop roots and water infiltration. Large plant materials and pebbles in the samples were separated by hand and discarded. Soil samples were air-dried, homogenized, sieved through $2 \mathrm{~mm}$ mesh and stored in polyethene bags at ambient temperature. Soil organic carbon (SOC) content was determined by the Walkley and Black method (Walkley and Black, 1934) with dichromate extraction and titrimetric quantization. Soil particle size (clay $<0.002 \mathrm{~mm}$, silt $=0.002-0.05 \mathrm{~mm}$, and sand $=0.05-2 \mathrm{~mm}$ ) was analyzed by the hydrometer method (Gee and Bauder, 1986). Soil water content based on the degree of saturation (SP) was also quantified following Blake and Hartge (1986) and Gardner (1986). The clod method (Blake and Hartge, 1986) was used to determine bulk density (BD) with three replications per sample site and depth interval. Electrical conductivity (EC) and $\mathrm{pH}$ values were measured in saturated paste extract using a digital EC-pH meter.

The exchangeable sodium $(\mathrm{Na})$ was measured using the method of Harron et al. (1983). CEC was analyzed according to Bower et al. (1952). Available phosphorus (P) and available potassium (K) were measured using standard procedures (Sparks et al., 1996). The calcium carbonate equivalent (CCE) was obtained by the back-titration technique (Nelson, 1982). Nitric acid-extractable forms of $\mathrm{Zn}, \mathrm{Cu}, \mathrm{Mn}$ and $\mathrm{Fe}$ were determined after extraction with $4 \mathrm{M} \mathrm{HNO}_{3}\left(1: 8\right.$ mass ratio of soil to final mixture) at $80^{\circ} \mathrm{C}$ for $16 \mathrm{~h}$. After cooling, samples were filtered through coarse acid washed cellulose filters. Ten $\mathrm{g}$ of soil was extracted with $20 \mathrm{ml}$ of $0.005 \mathrm{M}$ DTPA (diethylenetriaminepentaacetic acid) $+0.01 \mathrm{M}$ $\mathrm{TEA}+0.01 \mathrm{M} \mathrm{CaCl}_{2}$, adjusted to $\mathrm{pH} 7.3$ and shaken for $2 \mathrm{~h}$ to measure $\mathrm{Cu}, \mathrm{Mn}, \mathrm{Fe}$, and Zn DTPA forms (Lindsay and Norvell, 1978). In both cases, metal concentrations were determined using an atomic absorption system (Shimadzu model AA.670).

\subsection{Multivariate analysis}

Soil parameters were divided into two different groups: physical and chemical soil properties such as soil particle size, $\mathrm{SP}, \mathrm{BD}, \mathrm{OC}, \mathrm{pH}$, and $\mathrm{EC}$ ) and soil quality indicators such as soil nutrients and heavy metals. We included CEC in the soil quality indicator group because it is also considered an indicative property of minerals and nutrients in relation to soil texture and organic matter (Sulieman et al., 2018). The statistical parameters average, median, standard deviations and outliers of soil particle size (clay, silt, and sand), SP, BD, OC, pH, and EC were calculated and depicted in box plots to describe variability in the soil profile and the catchment (Fig. 3). We applied the One-Way ANOVA to test statistical differences between soil properties at the different depths when the properties were normality distributed as determined by the Shapiro-Wilk test and variances were equal. The Kruskal-Wallis One Way Analysis of Variance on Ranks test was used to determine statistical differences between soil properties when the Shapiro-Wilk normality test failed but variances were equal. The Tukey test was used to test statistical differences between soil properties when results were not normally distributed and variances were not equal. SigmaPlot v. 12.0 (Systat Software, Inc.) was used for these statistical 
analyses. Since not all the data followed a normal distribution, a Spearman rank coefficient was conducted to observe the correlation between variables.

To assess the soil properties that influenced soil quality indicators, a principal component analysis (PCA) was performed. Interpreting their influence on each factor, we were able to distinguish how important each factor was at the pedon and catchment scales at different soil depths. We selected a total of 6 components. Prior to conducting the PCA test, variables were centred and normalized in order to assign equal weights to all the variables and not misleading directions. To verify these assumptions, we applied a Kaiser-Mayer-Olkin (KMO) test of sphericity and calculated the coefficients and determinants. A PCA with an orthogonal rotation method (Varimax) and a correlation matrix, using factors with eigenvalues $>1$ was used.

\subsection{Soil quality index and mapping}

The development of a soil quality index and map usually includes three steps. First, appropriate indicators must be chosen. Second, the indicators are scored (0-1) in order to make a classification. A linear scoring method was used since the indicators are expressed with different numerical scales. Finally, the obtained indicator scores are combined into a unique and specific index, which can be mapped. The index in this study was based on an indicator sensitivity, where three different functions were assigned: 1) a "more is better" function; 2) a "less is better" function; and, 3) an "optimal range" function (Andrews et al., 2002; Mukherjee and Lal, 2014; Qi et al., 2009). To obtain the soil quality index (SQI), soil quality indicators have to be previously weighted. We assigned the weight value of each indicator using the communality value through the factor analysis that we elaborated previously. The equation used to develop the SQI was (Equation 1):

$$
I Q I=\sum_{i=1}^{n} W_{i} \cdot N_{i}
$$

where $\mathrm{SQI}$ is the soil quality index; $\mathrm{W}_{\mathrm{i}}$ is the weight of each indicator; and, $\mathrm{N}_{\mathrm{i}}$ represents the score of each indicator. In the current research, ten different soil quality indicators (CEC, total $\mathrm{N}$, Olsen-P, available $\mathrm{K}$, exchangeable $\mathrm{Na}$, calcium carbonate equivalent, $\mathrm{Fe}, \mathrm{Mn}, \mathrm{Zn}$, and $\mathrm{Cu}$ ) were used in the soil quality assessment and mapping. The soil quality map was generated using ordinary kriging in ArcMap 10.5 (ESRI, USA).

\section{Results}

\subsection{Soil properties and soil quality indicators at different depths}

Soil properties such as particle size, SP, BD, OC, $\mathrm{pH}$ values and EC at different depths (0-30 and 30-60 cm) were depicted in box plots to observe the average, median, maximum and minimum values (Fig. 3). Statistical differences between soil properties at different depths were also calculated (Table 1). At 0-30 cm, particle size was characterized by a loam texture $(32.1 \%, 49.6 \%$ and $18.3 \%$ for sand, silt, and clay, respectively). Similar average values were also observed at the 30-60 cm depth. SP (from 36 to 38\%), $\mathrm{pH}$ (8.1), and EC (from 1.9 to 2.3 $\mathrm{dS} \mathrm{m}^{-1}$ ) values were also similar at the two depths and did not show statistically significant differences. OC and BD also did show significant differences (Table 1) at the 0-30 and 30-60 $\mathrm{cm}$ depths. Average OC levels were low $(0.6 \%$ and $0.4 \%$ at the $0-30$ and $30-60 \mathrm{~cm}$ depths, respectively). Average BD values were $1.39 \mathrm{~g} / \mathrm{cm}^{-3}$ in the topsoil and $1.55 \mathrm{~g} / \mathrm{cm}^{-3}$ in the subsoil. 


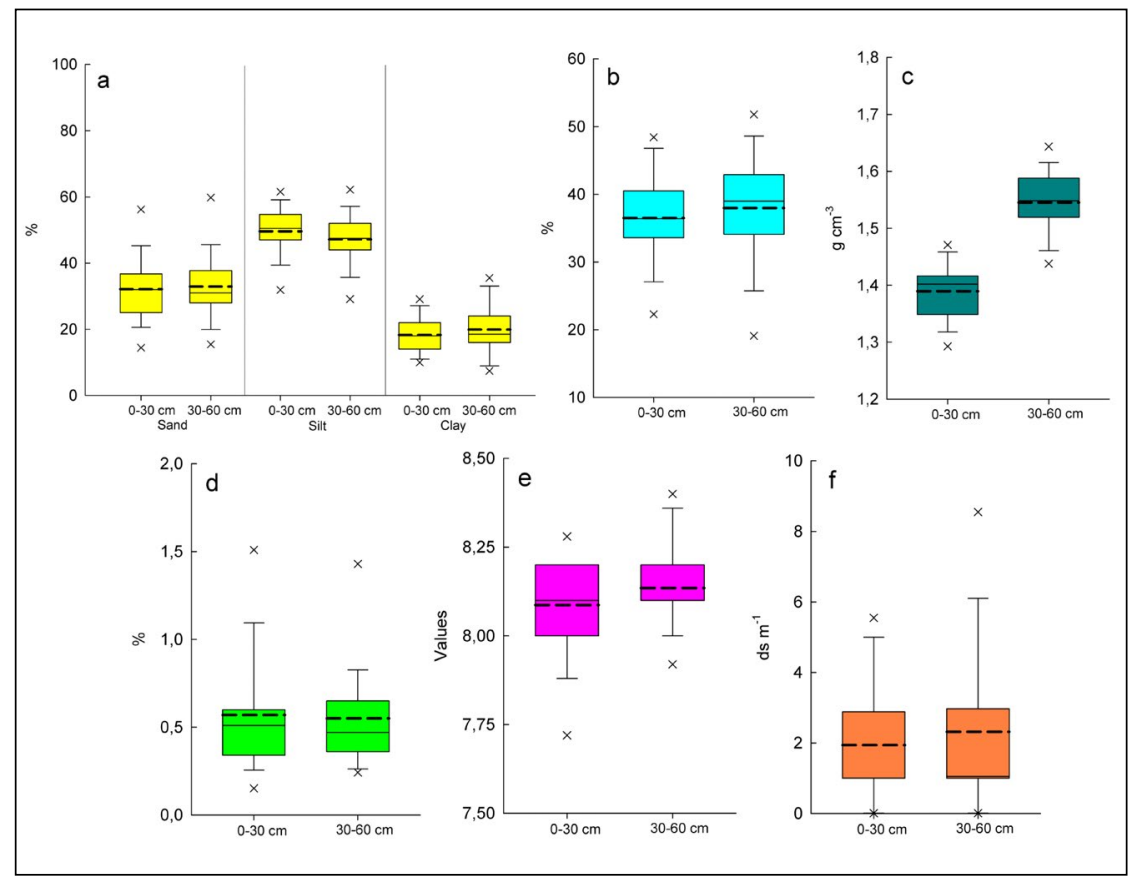

Figure 3. Box plots of soil properties at different soil depths $(0-30$ and $30-60 \mathrm{~cm})$. a: soil particle distribution; $b$ : water saturation percentage; $c$ : bulk density; $d$ : organic carbon; $e$ : $p H$ values; $f$ : electrical conductivity.

Table 1. Differences in soil properties and soil quality indicators between 0-30 and 30-60 cm depths.

\begin{tabular}{|c|c|c|}
\hline Soil parameter & $\boldsymbol{p}<$ & Different \\
\hline Sand & $0.854^{* *}$ & No \\
Silt & $0.083^{* *}$ & No \\
Clay & $0.067^{*}$ & No \\
SP & $0.253^{*}$ & No \\
BD & $0.001 * * *$ & Yes \\
OC & $0.004 * * *$ & Yes \\
pH & $0.660^{* *}$ & No \\
EC & $0.714 * *$ & No \\
\hline Soil quality indicator & $\boldsymbol{p}<$ & Different \\
\hline CEC & $0.180^{* *}$ & No \\
N & $0.034^{* * *}$ & Yes \\
P & $0.001 * * *$ & Yes \\
Ka & $0.012^{* * *}$ & Yes \\
CCE & $0.331 * *$ & No \\
Fe & $0.665^{* *}$ & No \\
Mn & $0.459 * *$ & No \\
Zn & $0.002^{* * *}$ & Yes \\
Cu & $0.002^{* * *}$ & Yes \\
\hline
\end{tabular}

SP: Water saturation percentage; BD: Bulk density; OC: Organic Carbon; EC: Electrical conductivity. *One-way ANOVA; **Kruskal Wallis; ***Tukey. 
The values and ranges of soil quality indicators (CEC, total N, Olsen-P, available $\mathrm{K}$ and exchangeable $\mathrm{Na}, \mathrm{CCE}, \mathrm{Fe}, \mathrm{Mn}, \mathrm{Zn}$ and $\mathrm{Cu}$ ) in the box plots (Fig. 4) and statistical comparisons are shown in Table 1. CEC did not show statistical differences with depth. Soil nutrients (total N, Olsen-P, and available K) showed statistical differences at the different depths, with the highest values in the 0-30 cm layer. CCE and exchangeable $\mathrm{Na}$ were not statistically different at the two depths; however, values for both were lower in the 0-30 cm depth than the 30-60 cm depth. Fe and $\mathrm{Cu}$ contents in the 0-30 and 30-60 $\mathrm{cm}$ depth intervals were also not significantly different. On the other hand, Mn and $\mathrm{Zn}$ showed significant statistical differences with both of them having higher contents in the 0-30 cm layer.

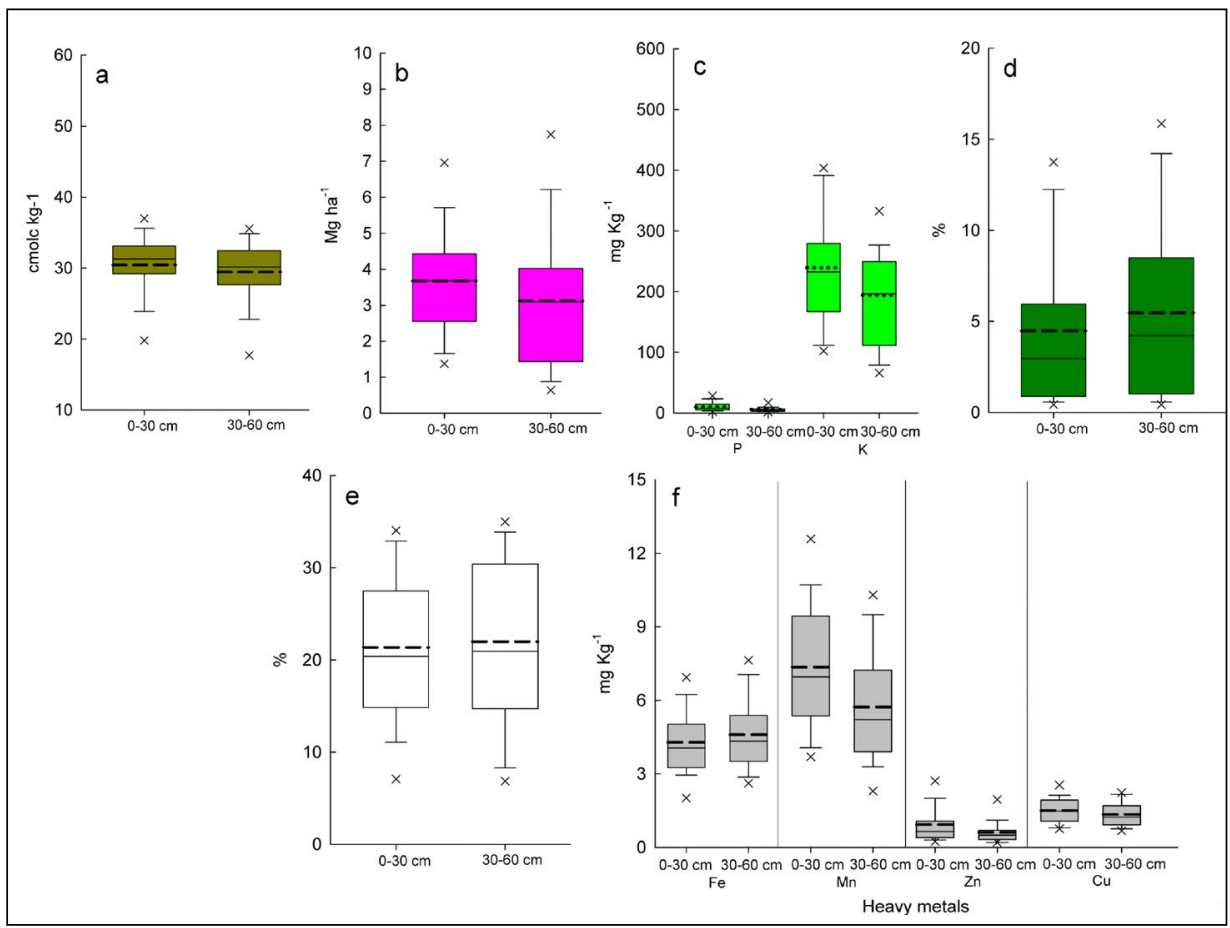

Figure 4. Box plots of soil quality indicators at different soil depths $(0-30$ and $30-60 \mathrm{~cm})$. a: cation-exchange capacity; $b$ : total $N$; $c$ : Olsen-P and available $K$; $d$ : available Na; e: calcium carbonate equivalent; $f$ : heavy metals.

\subsection{Correlations among variables at different soil depths}

Observing the relationships between selected soil properties and soil quality indicators allowed us to distinguish which parameters played important roles in the PCA. As almost none of the variables followed a normal distribution, a Spearman rank coefficient was conducted $\left(\mathrm{Sp}_{\mathrm{rc}}\right)$. Positive and negative results higher than 0.45 were considered to be indicative of correlation. 
Results of the Spearman analysis for the 0 to $30 \mathrm{~cm}$ interval are shown in Table 2. The highest correlations were found between sand and silt contents and CEC. OC had the highest number of correlations with soil quality indicators (four), those being total $\mathrm{N}$ $\left(\mathrm{Sp}_{\mathrm{rc}}>0.80\right)$, Olsen-P $\left(\mathrm{Sp}_{\mathrm{rc}}>0.55\right), \mathrm{Mn}\left(\mathrm{Sp}_{\mathrm{rc}}>0.57\right)$, and $\mathrm{Cu}\left(\mathrm{Sp}_{\mathrm{rc}}>0.57\right)$. Other relevant correlations between soil properties and soil indicators were: EC with exchangeable $\mathrm{Na}$, total $\mathrm{N}$ with Olsen-P and $\mathrm{Mn}$ with $\mathrm{Cu}$.

Table 2. Correlation between soil properties and soil quality indicators for the 0-30 cm depth interval.

\begin{tabular}{|c|c|c|c|c|c|c|c|c|c|c|}
\hline & CEC & $\mathbf{N}$ & $\mathbf{P}$ & $K$ & $\mathbf{N a}$ & CCE & $\mathrm{Fe}$ & Mn & $\mathbf{Z n}$ & $\mathrm{Cu}$ \\
\hline Sand & -0.87 & -0.34 & -0.16 & -0.30 & -0.27 & -0.07 & -0.18 & -0.31 & 0.05 & -0.37 \\
\hline Silt & 0.94 & 0.34 & 0.32 & 0.25 & 0.05 & -0.20 & 0.03 & 0.24 & 0.02 & 0.28 \\
\hline Clay & 0.26 & 0.23 & 0.02 & 0.21 & 0.46 & 0.35 & 0.17 & 0.16 & -0.05 & 0.25 \\
\hline SP & 0.43 & 0.43 & 0.18 & 0.39 & 0.38 & 0.02 & 0.38 & 0.39 & 0.02 & 0.45 \\
\hline BD & -0.40 & -0.38 & -0.14 & -0.27 & -0.47 & -0.27 & -0.26 & -0.31 & 0.01 & -0.37 \\
\hline OC & 0.43 & 0.80 & 0.55 & 0.34 & 0.41 & -0.26 & 0.44 & 0.57 & 0.24 & 0.57 \\
\hline pH & -0.19 & -0.03 & -0.01 & -0.12 & -0.28 & -0.01 & -0.10 & -0.10 & -0.10 & 0.01 \\
\hline EC & 0.23 & 0.20 & 0.24 & 0.30 & 0.71 & 0.03 & 0.25 & 0.14 & 0.09 & 0.09 \\
\hline CEC & & 0.36 & 0.24 & 0.32 & 0.16 & -0.13 & 0.12 & 0.31 & -0.02 & 0.36 \\
\hline $\mathbf{N}$ & & & 0.64 & 0.35 & 0.34 & -0.18 & 0.35 & 0.49 & 0.16 & 0.36 \\
\hline $\mathbf{P}$ & & & & 0.28 & 0.26 & -0.14 & 0.14 & 0.19 & 0.29 & 0.19 \\
\hline $\mathbf{K}$ & & & & & 0.17 & -0.23 & 0.09 & 0.29 & -0.24 & 0.26 \\
\hline $\mathrm{Na}$ & & & & & & -0.03 & 0.29 & 0.29 & 0.14 & 0.22 \\
\hline CCE & & & & & & & -0.24 & -0.55 & -0.13 & -0.46 \\
\hline $\mathrm{Fe}$ & & & & & & & & 0.45 & 0.29 & 0.34 \\
\hline Mn & & & & & & & & & 0.15 & 0.73 \\
\hline $\mathbf{Z n}$ & & & & & & & & & & 0.20 \\
\hline $\mathrm{Cu}$ & & & & & & & & & & \\
\hline
\end{tabular}

*SP: Water saturation percentage; BD: Bulk density; OC: Organic Carbon; EC: Electrical conductivity; CEC: Cation-exchange capacity; N: Total nitrogen; P: Olsen Phosphorus; K: Available potassium; Na: Exchangeable sodium; CCE: Calcium carbonate equivalent; Fe: Iron; Mn: Manganese; Zn: Zinc; Cu: Cupper.

At the 30-60 cm depth sand and silt again registered high correlations with CEC, and $\mathrm{OC}$ showed several correlations with the quality indicators total $\mathrm{N}, \mathrm{Fe}, \mathrm{Mn}$ and $\mathrm{Cu}$ (Table 3). Other strong correlations were found between EC and exchangeable $\mathrm{Na}, \mathrm{Fe}$ and $\mathrm{Mn}$ and $\mathrm{Mn}$ and $\mathrm{Cu}$ (Table 3). 
Table 3. Correlations between soil properties and soil quality parameters at the $30-60 \mathrm{~cm}$ depth interval.

\begin{tabular}{|c|c|c|c|c|c|c|c|c|c|c|}
\hline & CEC & $\mathbf{N}$ & $\mathbf{P}$ & $\mathbf{K}$ & CCE & $\mathrm{Na}$ & $\mathbf{F e}$ & Mn & $\mathbf{Z n}$ & $\mathbf{C u}$ \\
\hline Sand & -0.75 & -0.28 & -0.26 & -0.45 & -0.07 & -0.37 & -0.15 & -0.24 & -0.08 & -0.38 \\
\hline Silt & 0.92 & 0.12 & 0.21 & 0.11 & -0.14 & 0.06 & -0.02 & 0.12 & -0.18 & 0.19 \\
\hline Clay & 0.06 & 0.20 & 0.14 & 0.46 & 0.19 & 0.40 & 0.19 & 0.19 & 0.26 & 0.30 \\
\hline SP & 0.21 & 0.15 & 0.03 & 0.34 & 0.03 & 0.25 & 0.37 & 0.30 & 0.28 & 0.45 \\
\hline BD & -0.21 & -0.32 & -0.17 & -0.51 & -0.15 & -0.37 & -0.27 & -0.29 & -0.22 & -0.43 \\
\hline OC & 0.15 & 0.51 & 0.16 & 0.40 & -0.21 & -0.05 & 0.51 & 0.66 & -0.12 & 0.65 \\
\hline pH & -0.40 & 0.08 & -0.06 & -0.20 & -0.03 & -0.36 & 0.17 & 0.27 & -0.04 & 0.20 \\
\hline EC & 0.35 & -0.05 & 0.13 & 0.23 & 0.08 & 0.70 & -0.12 & -0.16 & 0.20 & 0.02 \\
\hline CEC & & 0.20 & 0.29 & 0.30 & -0.12 & 0.23 & 0.06 & 0.21 & -0.10 & 0.31 \\
\hline $\mathbf{N}$ & & & 0.20 & 0.29 & 0.30 & -0.12 & 0.23 & 0.06 & 0.21 & -0.10 \\
\hline $\mathbf{P}$ & & & & 0.30 & -0.15 & 0.38 & 0.06 & 0.18 & 0.13 & 0.32 \\
\hline $\mathbf{K}$ & & & & & -0.24 & 0.28 & 0.05 & 0.32 & -0.16 & 0.32 \\
\hline CCE & & & & & & -0.09 & -0.17 & -0.27 & 0.07 & -0.34 \\
\hline $\mathbf{N a}$ & & & & & & & 0.13 & 0.08 & 0.27 & 0.21 \\
\hline $\mathrm{Fe}$ & & & & & & & & 0.67 & 0.04 & 0.60 \\
\hline Mn & & & & & & & & & -0.10 & 0.72 \\
\hline $\mathrm{Zn}$ & & & & & & & & & & 0.15 \\
\hline $\mathrm{Cu}$ & & & & & & & & & & \\
\hline
\end{tabular}

*SP: Water saturation percentage; BD: Bulk density; OC: Organic Carbon; EC: Electrical conductivity; CEC: Cation-exchange capacity; N: Total nitrogen; P: Olsen Phosphorus; K: Available potassium; Na: Exchangeable sodium; CCE: Calcium carbonate equivalent; Fe: Iron; Mn: Manganese; Zn: Zinc; Cu: Cupper.

\subsection{Principal component analysis}

The total percentage of variance was added after conducting the principal component analysis (PCA) (Table 4). It was noted that six factors were able to explain a large amount of the variability $(82.1 \%)$ at the $0-30 \mathrm{~cm}$ depth; three components accounted for almost half $(49.5 \%)$. For the 30 to $60 \mathrm{~cm}$ depth, six components were able to explain $80.1 \%$ of the variability in the data; the first three components explained a total of $51.6 \%$.

Table 4. Total percentage of variance explained at the 0-30 and 30-60 cm depth intervals.

\begin{tabular}{|c|c|c|c|c|c|c|}
\hline \multirow[b]{2}{*}{$\begin{array}{c}\text { Compo- } \\
\text { nent }\end{array}$} & \multicolumn{3}{|c|}{$0-30 \mathrm{~cm}$} & \multicolumn{3}{|c|}{$30-60 \mathrm{~cm}$} \\
\hline & $\begin{array}{c}\text { Total rotated } \\
\text { component }\end{array}$ & $\begin{array}{c}\% \text { of } \\
\text { Variance }\end{array}$ & $\begin{array}{l}\text { Cumula- } \\
\text { tive \% }\end{array}$ & $\begin{array}{c}\text { Total rotated } \\
\text { component }\end{array}$ & $\begin{array}{c}\% \text { of Vari- } \\
\text { ance }\end{array}$ & $\begin{array}{l}\text { Cumula- } \\
\text { tive \% }\end{array}$ \\
\hline 1 & 3.61 & 20.1 & 20.1 & 3.40 & 18.9 & 18.9 \\
\hline 2 & 2.85 & 15.8 & 35.9 & 3.12 & 17.3 & 36.2 \\
\hline 3 & 2.45 & 13.6 & 49.5 & 2.78 & 15.4 & 51.6 \\
\hline 4 & 2.30 & 12.8 & 62.3 & 2.09 & 11.6 & 63.2 \\
\hline 5 & 2.16 & 12 & 74.3 & 1.65 & 9.2 & 72.4 \\
\hline 6 & 1.41 & 7.8 & 82.1 & 1.38 & 7.7 & 80.1 \\
\hline
\end{tabular}

At the 0-30 cm depth interval, the first component (accounting for $20.1 \%$ of the variability in soil analysis) was mainly determined by parameters related to soil particle sizes such as sand, clay, BD, OC and SP (Table 5). The second component illustrated the positive correlation 
between silt and CCE, and the negative correlation with sand (-0.78). The third component was composed of heavy metals such as $\mathrm{Mn}$ and $\mathrm{Cu}$ with $\mathrm{CCE}$. The fourth component showed the positive correlations between $\mathrm{EC}$ and exchangeable $\mathrm{Na}$ and a negative correlation with $\mathrm{pH}$ values. The fifth component grouped positive correlations of $\mathrm{OC}$ and soil nutrients (total $\mathrm{N}$ and Olsen-P). The last component included increases in available $\mathrm{K}$ and decreases in $\mathrm{Zn}$.

Table 5. Factors obtained from Principal Component Analysis at the 0-30 cm depth interval. Grey colours represent the selected variables.

\begin{tabular}{ccccccc}
\hline \multicolumn{7}{c}{ Component } \\
\hline Parameter & $\mathbf{1}$ & $\mathbf{2}$ & $\mathbf{3}$ & $\mathbf{4}$ & $\mathbf{5}$ & $\mathbf{6}$ \\
\hline Sand & -0.58 & -0.78 & -0.06 & -0.09 & -0.11 & -0.09 \\
Silt & 0.02 & 0.96 & 0.12 & 0.05 & 0.12 & 0.05 \\
Clay & 0.95 & 0.05 & -0.06 & 0.09 & 0.02 & 0.08 \\
SP & 0.83 & 0.20 & 0.21 & 0.06 & 0.24 & 0.11 \\
BD & -0.94 & -0.23 & -0.09 & -0.03 & -0.20 & -0.10 \\
OC & 0.52 & 0.10 & 0.41 & -0.14 & 0.56 & 0.07 \\
pH & 0.14 & -0.28 & 0.03 & -0.73 & 0.03 & 0.13 \\
EC & 0.02 & 0.06 & 0.00 & 0.96 & 0.04 & 0.04 \\
CEC & 0.27 & 0.93 & 0.10 & 0.10 & 0.12 & 0.06 \\
N & 0.27 & 0.22 & 0.25 & -0.07 & 0.79 & 0.17 \\
P & 0.02 & 0.17 & -0.02 & 0.02 & 0.85 & -0.11 \\
K & 0.10 & 0.24 & 0.16 & 0.08 & 0.26 & 0.70 \\
CCE & 0.37 & 0.05 & -0.77 & -0.07 & -0.10 & -0.19 \\
Na & 0.26 & -0.12 & 0.11 & 0.85 & 0.03 & 0.10 \\
Fe & 0.17 & -0.26 & 0.22 & 0.26 & 0.46 & 0.04 \\
Mn & 0.24 & 0.10 & 0.85 & 0.07 & 0.22 & 0.07 \\
Zn & -0.12 & 0.05 & 0.04 & 0.05 & 0.16 & -0.87 \\
Cu & 0.23 & 0.19 & 0.85 & -0.02 & 0.06 & -0.11 \\
\hline Component 1: Sand; Clay; SP; BD; OC. \\
\multicolumn{7}{c}{ Component 2: Sand; Silt; CEC. } \\
Component 3: CCE Mn. Cu. \\
Component 4: pH; EC; Na. \\
Component 5: OC; N; P. \\
Component 6: K; Zn. \\
W
\end{tabular}

*SP: Water saturation percentage; BD: Bulk density; OC: Organic Carbon; EC: Electrical conductivity; CEC: Cation-exchange capacity; N: Total nitrogen; P: Olsen Phosphorus; K: available potassium; Na: Exchangeable sodium; CCE: Calcium carbonate equivalent; Fe: Iron; Mn: Manganese; Zn: Zinc; Cu: Cupper.

The first component explained $18.9 \%$ of the variability in the subsoil layer (30-60 $\mathrm{cm}$ ) (Table 6). This component was characterized by increases in clay values and SP and decreases in sand and BD. The second component (36.2\%) included increases in OC, $\mathrm{Fe}, \mathrm{Mn}$ and $\mathrm{Cu}$. The third component grouped increases in silt and CEC with decreases in the sand. EC and exchangeable Na formed the fourth component. The presence of $\mathrm{N}$ was registered in the fifth component, which increased with the levels of total Olsen-P. Finally, the last component showed increases in CCEand decreases in available K. 
Table 6. Factors obtained from Principal Component Analysis at the 30-60 cm depth interval.

Grey colours represent the selected variables.

\begin{tabular}{|c|c|c|c|c|c|c|}
\hline \multicolumn{7}{|c|}{ Component } \\
\hline Parameter & 1 & 2 & 3 & 4 & 5 & 6 \\
\hline Sand & -0.60 & -0.09 & -0.75 & -0.12 & -0.14 & 0.02 \\
\hline Silt & -0.11 & 0.02 & 0.97 & 0.13 & 0.11 & -0.06 \\
\hline Clay & 0.97 & 0.10 & -0.01 & 0.03 & 0.08 & 0.03 \\
\hline SP & 0.83 & 0.26 & 0.17 & -0.07 & -0.02 & 0.09 \\
\hline $\mathrm{BD}$ & -0.91 & -0.27 & -0.14 & -0.05 & -0.21 & -0.04 \\
\hline OC & 0.02 & 0.73 & 0.03 & 0.00 & 0.49 & 0.07 \\
\hline $\mathrm{pH}$ & -0.07 & 0.45 & -0.42 & -0.46 & 0.07 & 0.14 \\
\hline $\mathrm{EC}$ & -0.15 & -0.06 & 0.20 & 0.93 & 0.06 & -0.02 \\
\hline CEC & 0.22 & 0.04 & 0.95 & 0.15 & 0.13 & -0.05 \\
\hline $\mathrm{N}$ & 0.04 & 0.32 & 0.05 & -0.06 & 0.79 & 0.13 \\
\hline $\mathrm{P}$ & 0.10 & 0.06 & 0.13 & 0.10 & 0.50 & -0.14 \\
\hline K & 0.38 & -0.06 & 0.11 & 0.16 & 0.49 & -0.63 \\
\hline CCE & 0.20 & -0.32 & 0.00 & -0.12 & 0.19 & 0.77 \\
\hline $\mathrm{Na}$ & 0.17 & 0.09 & 0.08 & 0.93 & 0.05 & -0.06 \\
\hline $\mathrm{Fe}$ & 0.21 & 0.82 & -0.10 & -0.06 & -0.04 & -0.03 \\
\hline $\mathrm{Mn}$ & 0.16 & 0.77 & 0.10 & 0.00 & 0.21 & -0.22 \\
\hline $\mathrm{Zn}$ & 0.36 & -0.07 & -0.14 & 0.12 & -0.32 & 0.47 \\
\hline $\mathrm{Cu}$ & 0.27 & 0.85 & 0.13 & 0.08 & 0.13 & -0.20 \\
\hline & $\begin{array}{r}\text { Compon } \\
\text { Compo } \\
\text { Compo } \\
\mathrm{Co} \\
\mathrm{Co}\end{array}$ & $\begin{array}{l}\text { t } 1: \mathrm{Sal} \\
\text { ent } 2: \mathrm{C} \\
\text { ent } 3: \mathrm{S} \\
\text { ponent } \\
\text { mpone } \\
\text { ponent }\end{array}$ & $\begin{array}{l}\text { Clay; } \\
\text { Fe; M } \\
\text { d; Silt; } \\
\text { EC; N } \\
5: \text { N; P } \\
\text { K; CC }\end{array}$ & $\begin{array}{l}\text { BD. } \\
\mathrm{Cu} . \\
\mathrm{EC} .\end{array}$ & & \\
\hline
\end{tabular}

*SP: Water saturation percentage; BD: Bulk density; OC: Organic Carbon; EC: Electrical conductivity; CEC: Cation-exchange capacity; N: Total nitrogen; $\mathrm{P}$ : Olsen Phosphorus; K: available potassium; Na: Exchangeable sodium; CCE: Calcium carbonate equivalent; Fe: Iron; Mn: Manganese; Zn: Zinc; Cu: Cupper.

\subsection{Soil quality indices}

The results of the paired-samples using the T-test for both the calculated soil quality indexes and the trend of soil quality index for topsoil and subsoil data are shown in Table 7 and Figure 5. The results showed that there was a significant difference $(<0.01)$, with average soil quality index values of 35.76 and 31.62 in the $0-30$ and $30-60 \mathrm{~cm}$ depth, respectively.

Table 7. Result of Paired-Samples T-test for soil quality indices.

\begin{tabular}{|c|c|c|c|}
\hline Soil quality indices & Mean & t-value & $\mathbf{p}=($ T-test $)$ \\
\hline Topsoil & 35.76 & 4.406 & $<0.001^{* *}$ \\
\hline Subsoil & 31.62 & & $<$ \\
\hline
\end{tabular}

** is significant at the 0.01 level. 


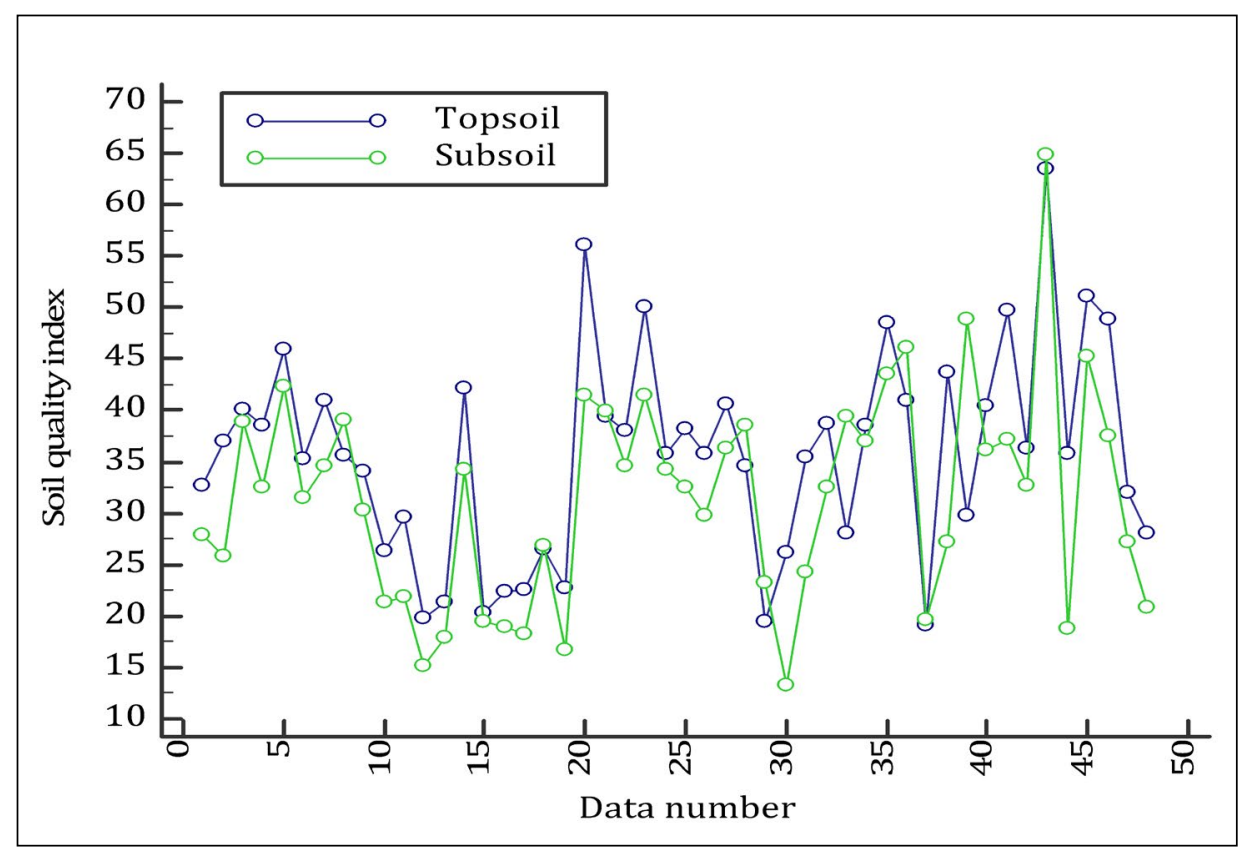

Figure 5. Trends in the soil quality index for topsoil and subsoil data.

To generate the soil quality index for the different soil depths, each soil quality indicator was assessed and weighted (Tables 8 and 9). Based on the communality analysis carried out before, $\mathrm{CEC}, \mathrm{Mn}, \mathrm{Zn}$, and $\mathrm{Cu}$ had the highest weights $(\geq 0.11)$ for both depths while exchangeable $\mathrm{Na}, \mathrm{CaCO}_{3}$, and $\mathrm{Fe}$ showed the lowest weights $(\leq 0.1)$. $\mathrm{N}, \mathrm{P}, \mathrm{K}$, and $\mathrm{Cu}$ had intermediate weights (0.1- 0.11).

Table 8. Communality and weight values of each soil quality indicator $(0-30 \mathrm{~cm})$.

\begin{tabular}{|c|c|c|}
\hline Soil quality indicator & Communality & Weight \\
\hline $\mathrm{CEC}$ & 0.844 & 0.12 \\
\hline $\mathrm{N}$ & 0.736 & 0.10 \\
\hline $\mathrm{P}$ & 0.748 & 0.10 \\
\hline $\mathrm{K}$ & 0.735 & 0.10 \\
\hline $\mathrm{Na}$ & 0.459 & 0.06 \\
\hline $\mathrm{CCE}$ & 0.697 & 0.096 \\
\hline $\mathrm{Fe}$ & 0.581 & 0.08 \\
\hline $\mathrm{Mn}$ & 0.796 & 0.11 \\
\hline $\mathrm{Zn}$ & 0.791 & 0.11 \\
\hline $\mathrm{Cu}$ & 0.778 & 0.11 \\
\hline
\end{tabular}

CEC: Cation-exchange capacity; N: Total nitrogen; P: Olsen Phosphorus; K: available potassium; Na: Exchangeable sodium; CCE: Calcium carbonate equivalent; Fe: Iron; Mn: Manganese; Zn: Zinc; Cu: Cupper. 
Table 9. Communality and weight values of each soil quality indicator $(30-60 \mathrm{~cm})$.

\begin{tabular}{|c|c|c|}
\hline Soil quality indicator & Communality & Weight \\
\hline $\mathrm{CEC}$ & 0.887 & 0.125 \\
\hline $\mathrm{N}$ & 0.682 & 0.096 \\
\hline $\mathrm{P}$ & 0.778 & 0.110 \\
\hline $\mathrm{K}$ & 0.650 & 0.092 \\
\hline $\mathrm{Na}$ & 0.389 & 0.055 \\
\hline $\mathrm{CCE}$ & 0.632 & 0.089 \\
\hline $\mathrm{Fe}$ & 0.592 & 0.083 \\
\hline $\mathrm{Mn}$ & 0.845 & 0.119 \\
\hline $\mathrm{Zn}$ & 0.840 & 0.118 \\
\hline $\mathrm{Cu}$ & 0.799 & 0.113 \\
\hline
\end{tabular}

CEC: Cation-exchange capacity; N: Total nitrogen; P: Olsen Phosphorus; K: Available potassium; Na: Exchangeable sodium; CCE: Carbonate calcium equivalent; Fe: Iron; Mn: Manganese; Zn: Zinc; $\mathrm{Cu}$ : Cupper.

Two maps of the soil quality indexes were generated (Fig. 6). Coefficients near zero indicate very low soil quality while results close to 100 represent areas with high quality as indicated by our selected soil quality indicator criteria. Higher soil quality was observed over larger areas in the 0-30 cm interval than at the 30-60 cm interval. The highest 0-30 cm soil quality index $(>48)$ was observed in the northwest part of the study area, while the lowest index $(<28)$ was in the middle part. A drastic decrease in soil quality was noted from the middle to the southern parts of the study area at 30-60 $\mathrm{cm}$. Only the northwest and northeast areas can be considered to be at an intermediate level of soil quality.

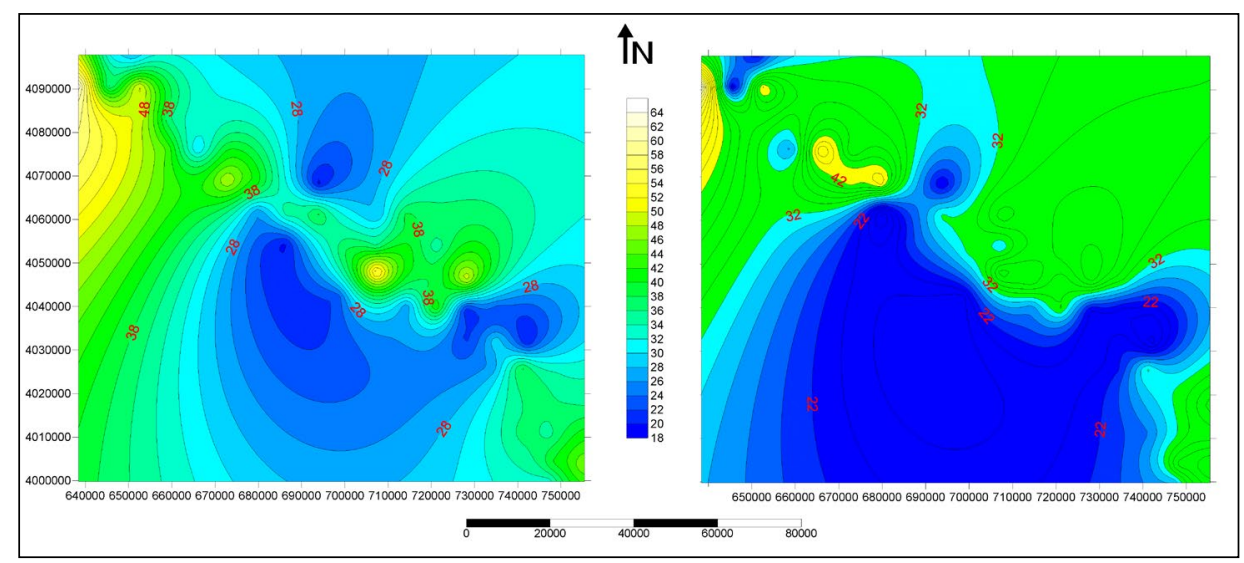

Figure 6. The spatial distribution of soil quality indices (left: $0-30 \mathrm{~cm}$, right: $30-60 \mathrm{~cm}$ ). 


\section{Discussion}

The identification of soil properties that control soil quality indicators is considered vital to plan appropriate soil management (Calleja-Cervantes et al., 2015). In semiarid areas with deep valleys that are cultivated and irrigated, such as in northeast Iran, appropriate soil and water management techniques are needed as important tools to conserve soil fertility and productivity (Samani et al., 2018). Assessing the relationships between soil properties and soil quality indicators, as was done in this research, will allow us to refine our interpretations of pedogenesis and soil horizon evolution due to a range of events from simple alterations of soil properties to degradation processes (Brimhall et al., 1991; Qadir et al., 2013; Sulieman et al., 2016).

In our study area, OC and BD were the soil properties with the highest variability at the pedon scale. In semiarid areas with strong human impacts due to cultivation, livestock or abandonment, the distribution of soil properties changes across the landscape and with depth (Acín-Carrera et al., 2013; Pulido et al., 2017). In most natural soils, OC is higher in the topsoil layers and decreases with depth, but in agricultural areas, the spatiotemporal variability can be very high and can affect plant vigour (Novara et al., 2018). Therefore, human impacts can be considered a factor driving these soil property changes. In the Mashhad Plain, the higher OC seen in the topsoil layer may be due to the use of amendments for the irrigated fields (García-Garizábal et al., 2017).

Increases in BD have been shown to reduce levels of soil organic matter (Brevik and Fenton, 2012), because it reduces soil aeration, root penetration, and makes it more difficult for organisms to move and conduct typical activities (Guo et al., 2016). Calcium carbonate content and textural changes were driving factors in the BD differences. The PCA demonstrated a high positive correlation between BD, clay content, and sand. We concluded that soil particle size and carbonate content contributed to significant statistical differences between soil depths. It is also well known that BD increases with increasing depth, even without changes in texture or carbonate content, because the weight of the overlying soil compresses the deeper, underlying soil (Al-Shammary et al., 2018).

Cation exchange capacity is a useful soil quality indicator that represents the soil's ability to hold positively charged ions. Correlation analyses, PCA and the soil quality index showed that at 0-30 and 30-60 cm there was a strong correlation between CEC and soil particle size, specifically, a negative relationship with sand and positive correlation with silt and high soil quality. A strong correlation with clay would typically be expected (Mamedov et al., 2017; Sulieman et al., 2018). However, Khaledian et al. (2017a) also found that CEC was not strongly correlated with clay in Spain when they modelled CEC for different countries. Khaledian et al. (2017a) hypothesized that the lack of correlation between clay and CEC in the Spanish soils might be due to the long-term intensive agricultural management that had led to the creation of highly degraded soils. That situation is highly similar to our experimental area. However, in our study area, the physiographic position on the alluvial plain with conglomerates and fine materials (Fig. 2) possibly means the soils developed in a thick sediment-dominated environment belonging to the Quaternary period, and this also may have affected this correlation (Keshavarzi et al., 2016, 2018). 
Organic carbon had the highest number of correlated soil quality indicators; two of them were heavy metals (Mn and $\mathrm{Cu}$ ). Pezeshki and DeLaune (2012) concluded that $\mathrm{Mn}$ is an essential plant micronutrient that is well correlated with $\mathrm{OC}$ and total $\mathrm{N}$ and P. They also observed that a decrease in soil tillage or increase in soil humidity could affect their levels. However, Sparrow and Uren (2014) indicated that high levels of Mn could damage crops. Thus, appropriate management of $\mathrm{Mn}$ is essential, with organic amendments often producing better results than chemical products (Tao et al., 2007). We also observed that increases in some soil nutrients such as Olsen-P and available $\mathrm{K}$ or exchangeable $\mathrm{Na}$ corresponded to increased levels of $\mathrm{Fe}, \mathrm{Cu}$, and $\mathrm{Zn}$. High concentrations of heavy metals in soils are considered dangerous for plant, animal, and human health (Rinot et al., 2018) and increasing their levels is not typically recommended (Chen et al., 2015; Fernández-Calviño et al., 2017), although $\mathrm{Fe}, \mathrm{Cu}$, and $\mathrm{Zn}$ are all essential human nutrients and do need to be present in small amounts (Steffan et al., 2018). We observed a positive correlation at the surface $(0-30 \mathrm{~cm})$ between organic matter, Fe, $\mathrm{Mn}$ and $\mathrm{Cu}$; other researchers have also reported positive correlations between organic matter and metals (Gao and Chen, 2012; Kargar et al., 2015; Khaledian et al., 2017b). Further studies in this area could be focused on the relationships between organic matter, heavy metals and exchangeable $\mathrm{Na}$, and soil fertility by applying pedotransfer functions or fractal analysis (Hosseini et al., 2017; Keshavarzi et al., 2018).

Our maps show that soil quality was higher in the 0-30 cm layer than at 30-60 $\mathrm{cm}$. We observed that the areas of lowest soil quality extended from the middle part of the study area to the south, coinciding with flat and cultivated areas. Soil can serve as a filter that protects groundwater from pollutants, but if not well managed, the utility of soil as a filter can be overwhelmed or eliminated (Keesstra et al., 2012). In fact, in some cases, soil can actually become a source of water contamination (Steffan et al., 2018). At this level, possible nature-based solutions must be evaluated, by using concepts such as connectivity (López-Vicente et al., 2013) that allow us to think of suitable management as a guide to evaluate control strategies. To achieve this goal, new advances in mapping the spatial distribution of soil properties and land use changes can contribute to improvements in soil management (Kharazmi et al., 2018). This coincides with the main goal of our research, which was to use knowledge of the interrelationships between soil parameters to allow predictions of their spatial variability at the pedon scale.

\section{Conclusions}

We demonstrated that the statistical assessment of soil properties and soil quality indicators can be a useful tool to detect the factors that condition soil evolution and fertility. In the Mashhad Plain of northeast Iran, we found significant differences in select soil properties between $0-30$ and $30-60 \mathrm{~cm}$ depth intervals. The multivariate analysis demonstrated that OC, bulk density, and CEC showed the highest correlations with the other soil physicochemical properties, showing their potential as soil characterization predictors. A soil quality index was developed using $\mathrm{CEC}, \mathrm{Mn}, \mathrm{Zn}$, and $\mathrm{Cu}$ as soil quality indicators. Soil quality maps showed that heavy metals were key factors causing soil 
degradation in the 30-60 cm depth interval. These kinds of relationships are influenced by several factors, which in turn has the potential to affect soil and water quality and fertility. This must be considered in land management plans. Therefore, one direction of future research should focus on detecting the spatial variation of potential contaminants across the Mashhad Plain, paying particular attention to hotspots with high levels of soil contamination.

\section{Acknowledgements}

This study was partially supported by the Department of Soil Science, University of Tehran, Iran.

\section{References}

Acín-Carrera, M., José Marqués, M., Carral, P., Álvarez, A.M., López, C., Martín-López, B., González, J.A. 2013. Impacts of land-use intensity on soil organic carbon content, soil structure and water-holding capacity. Soil Use Management 29, 547-556. https://doi. org/10.1111/sum.12064.

Al-Shammary, A.A.G., Kouzani, A.Z., Kaynak, A., Khoo, S.Y., Norton, M., Gates, W. 2018. Soil bulk density estimation methods: A Review. Pedosphere 28 (4), 581-596. https://doi. org/10.1016/S1002-0160(18)60034-7.

Andrews, S.S., Mitchell, J.P., Mancinelli, R., Karlen, D.L., Hartz, T.K., Horwath, W.R., Pettygrove, G.S., Scow, K.M., Munk, D.S. 2002. On-farm assessment of soil quality in California's Central Valley. Agronomy Journal 94 (1), 12-23. https://doi.org/10.2134/agronj2002.1200.

Armenise, E., Redmile-Gordon, M.A., Stellacci, A.M., Ciccarese, A., Rubino, P. 2013. Developing a soil quality index to compare soil fitness for agricultural use under different managements in the Mediterranean environment. Soil \& Tillage Research 130,91-98. https:// doi.org/10.1016/j.still.2013.02.013.

Arnab, R. 2017. Chapter 7. Stratified Sampling. In: R. Arnab (Ed.), Survey Sampling Theory and Applications. Academic Press, pp. 213-256. https://doi.org/10.1016/B978-0-12-8118481.00007-8.

Blake, G.R., Hartge, K.H. 1986. Bulk density. In: A. Klute (Ed.), Methods of Soil Analysis Part 1. Physical and Mineralogical Methods. Agronomy Monograph 9, $2^{\text {nd }}$ Edition. American Society of Agronomy, Soil Science Society of America. Madison, Wisconsin, USA. pp. 363375.

Bower, C.A., Reitemeier, R.F., Fireman, M. 1952. Exchangeable cation analysis of saline and alkali soils. Soil Science 73 (4), 251-261. http://doi.org/10.1097/00010694-19520400000001 .

Brevik, E.C., Fenton, T.E. 2012. Long-term effects of compaction on soil properties along the Mormon Trail, south-central Iowa, USA. Soil Horizons 53 (5), 37-42.https://doi.org/10.2136/ sh12-03-0011.

Brimhall, G.H., Christopher J.,L., Ford, Ch., Bratt, J., Taylor, G., Warin, O. 1991. Quantitative geochemical approach to pedogenesis: importance of parent material reduction, volumetric expansion, and eolian influx in lateritization. Geoderma 51 (1-4), 51-91. https://doi. org/10.1016/0016-7061(91)90066-3.

Bruand, A., Tessier, D. 2000. Water retention properties of the clay in soils developed on clayey sediments: significance of parent material and soil history. European Journal of Soil Science 51, 679-688. https://doi.org/10.1111/j.1365-2389.2000.00338.x. 
Calleja-Cervantes, M.E., Fernández-González, A.J., Irigoyen, I., Fernández-López, M., AparicioTejo, P.M., Menéndez, S. 2015. Thirteen years of continued application of composted organic wastes in a vineyard modify soil quality characteristics. Soil Biology and Biochemistry 90 , 241-254. https://doi.org/10.1016/j.soilbio.2015.07.002.

Chen, M., Xu, P., Zeng, G., Yang, C., Huang, D., Zhang, J. 2015. Bioremediation of soils contaminated with polycyclic aromatic hydrocarbons, petroleum, pesticides, chlorophenols and heavy metals by composting: Applications, microbes and future research needs. Biotechnological Advances 33, 745-755. https://doi.org/10.1016/j.biotechadv.2015.05.003.

Christofides, T.C., 2005. Randomized response in stratified sampling. Journal of Statistical Planning and Inference 128 (1), 303-310. https://doi.org/10.1016/j.jspi.2003.11.001.

Fernández-Calviño, D., Cutillas-Barreiro, L., Núñez-Delgado, A., Fernández-Sanjurjo, M.J., Álvarez-Rodríguez, E., Nóvoa-Muñoz, J.C., Arias-Estévez, M. 2017. Cu immobilization and Lolium perenne development in an acid vineyard soil amended with crushed mussel shell. Land Degradation \& Development 28 (2), 762-772. https://doi.org/10.1002/ldr.2634.

Gao, X., Chen, Ch-T.A. 2012. Heavy metal pollution status in surface sediments of the coastal Bohai Bay. Water Research 46 (6), 1901-1911. https://doi.org/10.1016/j.watres.2012.01.007.

García-Garizábal, I., Causapé, J., Merchán, D. 2017. Evaluation of alternatives for flood irrigation and water usage in Spain under Mediterranean climate. Catena 155, 127-134. https://doi. org/10.1016/j.catena.2017.02.019.

García-Ruiz, J.M., Beguería, S., Nadal-Romero, E., González-Hidalgo, J.C., Lana-Renault, N., Sanjuán, Y. 2015. A meta-analysis of soil erosion rates across the world. Geomorphology 239, 160-173. https://doi.org/10.1016/j.geomorph.2015.03.008.

Gardner, W.H. 1986. Water content. In: A. Klute (Ed.), Methods of Soil Analysis Part 1. Physical and Mineralogical Methods, Agronomy Monograph 9, $2^{\text {nd }}$ Edition. American Society of Agronomy, Soil Science Society of America. Madison, Wisconsin, USA, pp. 493-544.

Gee, G.W., Bauder, J.W. 1986. Particle size analysis. In: A. Klute (Ed.), Methods of Soil Analysis: Part 1. Physical and Mineralogical Methods. Agronomy Monograph $9,2^{\text {nd }}$ Edition. American Society of Agronomy and Soil Science Society of America, Madison, Wisconsin, USA, pp. 383-411.

Guo, L., Wu, G., Li, Y., Li, C., Liu, W., Meng, J., Liu, H., Yu, X., Jiang, G. 2016. Effects of cattle manure compost combined with chemical fertilizer on topsoil organic matter, bulk density and earthworm activity in a wheat-maize rotation system in Eastern China. Soil \& Tillage Research 156, 140-147. https://doi.org/10.1016/j.still.2015.10.010.

Gutzler, C., Helming, K., Balla, D., Dannowski, R., Deumlich, D., Glemnitz, M., Knierim, A., Mirschel, W., Nendel, C., Paul, C., Sieber, S., Stachow, U., Starick, A., Wieland, R., Wurbs, A., Zander, P. 2015. Agricultural land use changes - a scenario-based sustainability impact assessment for Brandenburg, Germany. Ecological Indicators 48, 505-517. https://doi. org/10.1016/j.ecolind.2014.09.004.

Harron, W.R.A., Webster, G.R., Cairns, R.R. 1983. Relationship between exchangeable sodium and sodium adsorption ratio in a solonetzic soil association. Canadian Journal of Soil Science 63 (3), 461-467. https://doi.org/10.4141/cjss83-047.

Hosseini, M., Rajabi Agereh,S., Khaledian, Y., Jafarzadeh Zoghalchali, H., Brevik, E.C., Movahedi Naeini, S.A.R. 2017. Comparison of multiple statistical techniques to predict soil phosphorus. Applied Soil Ecology 114, 123-131. https://doi.org/10.1016/j.apsoil.2017.02.011.

IUSS Working Group WRB 2014. World Reference Base for Soil Resources 2014, World Soil Resources Report. FAO, Rome.

Kargar, M., Clark, O.G., Hendershot, W.H., Jutras, P., Prasher, S. 2015. Inmobilization of trace metals in contaminated urban soil amended with compost and biochar. Water, Air, and Soil Pollution 226 (6), 191. https://doi.org/10.1007/s11270-015-2450-2. 
Keesstra, S., Geissen, V., Mosse, K., Piiranen, S., Scudiero, E., Leistra, M., van Schaik, L. 2012. Soil as a filter for groundwater quality. Current. Opinion in Environmental Sustainability 4, 507-516. https://doi.org/10.1016/j.cosust.2012.10.007.

Keshavarzi, A., Omran, E.S.E., Bateni, S.M., Pradhan, B., Vasu, D., Bagherzadeh, A. 2016. Modeling of available soil phosphorus (ASP) using multi-objective group method of data handling. Modeling Earth Systems and Environment 2, 157. https://doi.org/10.1007/s40808016-0216-5.

Keshavarzi, A., Tuffour, H., Bagherzadeh, A., Vasu,D.V. 2018. Spatial and fractal characterization of soil properties across soil depth in an agricultural field, Northeast Iran. Eurasian Journal of Soil Science 7 (2), 35-45. https://doi.org/10.18393/ejss.339032.

Khaledian, Y., Brevik, E., Pereira, P., Cerdà, A., Fattah, M., Tazikeh, H. 2017a. Modeling soil cation exchange capacity in multiple countries. Catena 158, 194-200. https://doi. org/10.1016/j.catena.2017.07.002.

Khaledian, Y., Pereira, P., Brevik, E.C., Pundyte, N., Paliulis, D. 2017b. The influence of organic carbon and $\mathrm{pH}$ on heavy metals, potassium, and magnesium levels in Lithuanian Podzols. Land Degradation \& Development 28 (1), 345-354. https://doi.org/10.1002/ldr.2638.

Kharazmi, R., Tavili, A., Rahdari, M.R., Chaban, L., Panidi, E., Rodrigo-Comino, J. 2018. Monitoring and assessment of seasonal land cover changes using remote sensing: a 30year (1987-2016) case study of Hamoun Wetland, Iran. Environmental Monitoring and Assessment 190 (6), 356. https://doi.org/10.1007/s10661-018-6726-z.

Li, C., Li, F., Wu, Z., Cheng, J. 2017. Exploring spatially varying and scale-dependent relationships between soil contamination and landscape patterns using geographically weighted regression. Applied Geography 82, 101-114. https://doi.org/10.1016/j.apgeog.2017.03.007.

Lindsay, W.L., Norvell, W.A. 1978. Development of a DTPA Soil Test for Zinc, Iron, Manganese, and Copper. Soil Science Society of America Journal 42, 421-428. https://doi.org/10.2136/ sssaj1978.03615995004200030009x.

Liu, J., Wu, L., Chen, D., Li, M., Wei, C. 2017. Soil quality assessment of different Camellia oleifera stands in mid-subtropical China. Applied Soil Ecology 113, 29-35. https://doi. org/10.1016/j.apsoil.2017.01.010.

López-Vicente, M., Poesen, J., Navas, A., Gaspar, L. 2013. Predicting runoff and sediment connectivity and soil erosion by water for different land use scenarios in the Spanish PrePyrenees. Catena 102, 62-73. https://doi.org/10.1016/j.catena.2011.01.001.

Mamedov, A.I., Huang, C., Aliev, F.A., Levy, G.J. 2017. Aggregate stability and water retention near saturation characteristics as affected by soil texture, aggregate size and polyacrylamide application. Land Degradation \& Development 28, 543-552. https://doi.org/10.1002/ ldr.2509.

Mukherjee, A., Lal, R. 2014. Comparison of soil quality index using three methods. PLOS ONE 9, e105981. https://doi.org/10.1371/journal.pone.0105981.

Mwango, S.B., Msanya, B.M., Mtakwa, P.W., Kimaro, D.N., Deckers, J., Poesen, J. 2015. Effectiveness of mulching under Miraba in controlling soil erosion, fertility restoration and crop yield in the Usambara Mountains, Tanzania. Land Degradation \& Development 27, 1266-1275. https://doi.org/10.1002/ldr.2332.

Nasri, B., Fouché, O., Torri, D. 2015. Coupling published pedotransfer functions for the estimation of bulk density and saturated hydraulic conductivity in stony soils. Catena 131, 99-108. https://doi.org/10.1016/j.catena.2015.03.018.

Nelson, D.W., Sommers, L.P. 1986. Total carbon, organic carbon and organic matter. In: A.L. Page (Ed.) Methods of Soil Analysis Part 2. Chemical and Microbiological Properties. Agronomy Series 9, $2^{\text {nd }}$ Edition, American Society of Agronomy, Soil Science Society of America. Madison, Wisconsin, USA, pp. 539-579. 
Novara, A., Pisciotta, A., Minacapilli, M., Maltese, A., Capodici, F., Cerdà, A., Gristina, L. 2018. The impact of soil erosion on soil fertility and vine vigor. A multidisciplinary approach based on field, laboratory and remote sensing approaches. Science of the Total Environment 622623, 474-480. https://doi.org/10.1016/j.scitotenv.2017.11.272.

Pezeshki, S.R., DeLaune, R.D. 2012. Soil oxidation-reduction in wetlands and its impact on plant functioning. Biology 1 (2), 196-221. https://doi.org/10.3390/biology 1020196.

Pulido, M., Schnabel, S., Lavado Contador, J.F., Lozano-Parra, J., Gómez-Gutiérrez, Á., Brevik, E.C., Cerdà, A. 2017. Reduction of the frequency of herbaceous roots as an effect of soil compaction induced by heavy grazing in rangelands of SW Spain. Catena 158, 381-389. https://doi.org/10.1016/j.catena.2017.07.019.

Qadir, M., Noble, A.D., Chartres, C. 2013. Adapting to climate change by improving water productivity of soils in dry areas. Land Degradation \& Development $24,12-21$. https://doi. org/10.1002/ldr.1091.

Qi, Y., Darilek, J.L., Huang, B., Zhao, Y., Sun, W., Gu, Z. 2009. Evaluating soil quality indices in an agricultural region of Jiangsu Province, China. Geoderma 149, 325-334. https://doi. org/10.1016/j.geoderma.2008.12.015.

Rinot, O., Levy, G.J., Steinberger, Y., Svoray, T., Eshel, G. 2018. Soil health assessment: A critical review of current methodologies and a proposed new approach. Science of the Total Environment 648, 1484-1491. https://doi.org/10.1016/j.scitotenv.2018.08.259.

Samani, A.N., Rad, F.T., Azarakhshi, M., Rahdari, M.R., Rodrigo-Comino, J. 2018. Assessment of the sustainability of the territories affected by gully head advancements through aerial photography and modeling estimations: A Case Study on Samal Watershed, Iran. Sustainability 10 (8), 2909. https://doi.org/10.3390/su10082909.

Shiri, J., Keshavarzi, A., Kisi, O., Iturraran-Viveros, U., Bagherzadeh, A., Mousavi, R., Karimi, S. 2017. Modeling soil cation exchange capacity using soil parameters: Assessing the heuristic models. Computers and Electronics in Agriculture 135, 242-251. https://doi.org/10.1016/j. compag.2017.02.016.

Singer, M.J., Shainberg, I. 2004. Mineral soil surface crusts and wind and water erosion. Earth Surface Processes and Landforms 29, 1065-1075. https://doi.org/10.1002/esp.1102.

Sparks, D.L., Page, A.L., Helmke, P.A., Loeppert, R.H. 1996. Methods of Soil Analysis Part 3-Chemical Methods. Soil Science Society of America Book Series 5.3. Soil Science Society of America, American Society of Agronomy, Madison, Wisconsin, USA. Available at https:// dl.sciencesocieties.org/publications/books/tocs/sssabookseries/methodsofsoilan3.

Sparrow, L., Uren, N. 2014. Manganese oxidation and reduction in soils: Effects of temperature, water potential, $\mathrm{pH}$ and their interactions. Soil Research 52, 483. https://doi.org/10.1071/ SR13159.

Steffan, J.J., Brevik, E.C., Burgess, L.C., Cerdà, A. 2018. The effect of soil on human health: an overview. European Journal of Soil Science 69, 159-171. https://doi.org/10.1111/ ejss.12451.

Sulieman, M., Saeed, I., Hassaballa, A., Rodrigo-Comino, J. 2018. Modeling cation exchange capacity in multi geochronological-derived alluvium soils: An approach based on soil depth intervals. Catena 167,327-339. https://doi.org/10.1016/j.catena.2018.05.001.

Sulieman, M.M., Ibrahim, I.S., Elfaki, J.T. 2016. Genesis and classification of some soils of the River Nile terraces: a case study of Khartoum North, Sudan. Journal of Geoscience and Environment Protection 4, 1-16. https://doi.org/10.4236/gep.2016.43001.

Tao, H., Dittert, K., Zhang, L., Lin, S., Römheld, V., Sattelmacher, B. 2007. Effects of soil water content on growth, tillering, and manganese uptake of lowland rice grown in the watersaving ground-cover rice-production system (GCRPS). Journal of Plant Nutrition and Soil Science 170, 7-13. https://doi.org/10.1002/jpln.200625033. 
Torres-Sallan, G., Schulte, R.P.O., Lanigan, G.J., Byrne, K.A., Reidy, B., Simó, I., Six, J., Creamer, R.E. 2017. Clay illuviation provides a long-term sink for $\mathrm{C}$ sequestration in subsoils. Scientific Reports 7, 45635. https://doi.org/10.1038/srep45635.

Walkley, A., Black, I.A. 1934. An examination of the Degtjareff method for determining soil organic matter, and a proposed modification of the chromic acid titration method. Soil Science 37 (1), 29-38. http://doi.org/10.1097/00010694-193401000-00003.

Wang, J., Liu, L., Qiu, X., Wei, Y., Li, Y., Shi, Z. 2016. Contents of soil organic carbon and nitrogen in water-stable aggregates in abandoned agricultural lands in an arid ecosystem of Northwest China. Journal of Arid Land 8 (3), 350-363. https://doi.org/10.1007/s40333-0160042-7.

Wang, K., Zhang, C., Li, W. 2013. Predictive mapping of soil total nitrogen at a regional scale: A comparison between geographically weighted regression and cokriging. Applied Geography 42, 73-85. https://doi.org/10.1016/j.apgeog.2013.04.002.

Zeraatpishe, M., Khormali, F. 2012. Carbon stock and mineral factors controlling soil organic carbon in a climatic gradient, Golestan province. Journal of Soil Science and Plant Nutrition 12 (4), 637-654. https://doi.org/10.4067/S0718-95162012005000022. 